\title{
Computer-supported games and role plays in teaching water management
}

\author{
A. Y. Hoekstra \\ University of Twente, P.O. Box 217, 7500 AE Enschede, The Netherlands \\ Correspondence to: A. Y. Hoekstra (a.y.hoekstra@utwente.nl) \\ Received: 29 January 2012 - Published in Hydrol. Earth Syst. Sci. Discuss.: 9 February 2012 \\ Revised: 11 July 2012 - Accepted: 7 August 2012 - Published: 27 August 2012
}

\begin{abstract}
There is an increasing demand for an interdisciplinary approach in teaching water management. Computersupported games and role plays offer the potential of creating an environment in which different disciplines come together and in which students are challenged to develop integrated understanding. Two examples are discussed. The River Basin Game is a common-pool resource game in which participants experience the risk of over-abstractions of water in a river basin and learn how this risk relates to the complexity of the system, the conflict between individual and group optimums and the difficulty in achieving good cooperation. The Globalization of Water Role Play makes participants familiar with the global dimension of water management by letting them experience how national governments can integrate considerations of water scarcity and domestic water productivities into decisions on international trade in commodities like food, cotton and bio-energy. The two examples illustrate that play sessions inspire participants to think about the functioning of systems as a whole and to develop good cooperative courses of action, whereby both uncertainties about the system and the presence of different values and perspectives among participants play a role.
\end{abstract}

\section{Introduction}

There are two trends that together require a reflection on the traditional way in which hydrology and water management are taught. These trends are:

1. An interdisciplinary approach is increasingly being recognised as crucial in proper understanding of the interaction between humans and the Earth system.
2. Advances in computer technology, the increasing extent to which students are accustomed to computer-aided education, and positive experiences with active learning in various other educational contexts invite for the exploration of new ways of learning.

The relevance of the social sciences in water resources education was already acknowledged in the 1960s (Hufschmidt, 1967). Even earlier, Wittfogel (1957) wrote about the relations between irrigation works and societal organisation and politics in ancient civilizations. In the second half of the 1980s, the call for an interdisciplinary approach in understanding the relation between water and society and in developing water policy led to the establishment of the concept of Integrated Water Resources Management (IWRM). The emergence of the concept of sustainable development in the same period reinforced the call for interdisciplinary approaches in teaching. In practice, however, the adoption of interdisciplinary approaches in teaching is slowed down by the traditional organisation of teaching along disciplines. In most countries, university education in hydrology and water management is part of civil engineering or physical geography curricula, with either an engineering or a natural scientific focus, with at best some but limited attention to the social scientific dimension of water management. This is not to say that there are no good examples (see, e.g. Blöschl et al., 2012; Uhlenbrook and De Jong, 2012), but they remain exceptions from a global perspective. For most hydrology or water management curricula, it remains a challenge to bring in the wider perspective.

McLaughlan (2007) makes a distinction between teaching content and teaching methods. He argues that the societal call for sustainable development has led to some extent to the incorporation of sustainable development criteria 
Table 1. Simulation games and role plays in hydrology and water management.

\begin{tabular}{lll}
\hline Game/role play & Field & Reference(s) \\
\hline Water demand management role play & Water demand management within a river basin & Porte Agel et al. (1996) \\
STORM-RR role play & Floodplain management for a river stretch & Schmidt (1998) \\
$\begin{array}{l}\text { Ravilla-2 role play } \\
\text { Role play international rivers }\end{array}$ & Water resources allocation under different institutional settings & Farczadi et al. (1999, 2008) \\
River basin game & Shared vision and strategy development for a transboundary river & Jaspers (2002) \\
& Water allocation for irrigation in a river basin & Lankford et al. (2004); \\
River basin game & & Magombeyi et al. (2008) \\
Globalization of water role play & Managing conflict over water as a common-pool resource & Hoekstra (2007) \\
Wastewater role playing game & Water resources allocation in an international context & Hoekstra et al. (2009) \\
LASY role play & Water policy development within a river basin & Prat et al. (2009) \\
Sustainable delta Waas game & River flood management & Valkering et al. (2009) \\
& & Haasnoot and Van Beek (2010), \\
& & Van Deursen et al. (2010), \\
LIBRA river basin simulation game & Integrated river basin planning & Valkering et al. (2012) \\
Irrigania game & Web-based game about sharing water resources & Heun (2011) \\
\hline
\end{tabular}

into undergraduate engineering accreditation requirements and the integration of relevant knowledge and skills into the curricula, but that less focus has been on the type of instructional strategies needed to create the integrated and interdisciplinary perspective required for sustainability education. McLaughlan (2007) and also others, like Maier et al. (2007), argue that active learning strategies such as role play simulation, online debates and scenario building can be very effective, because such learning strategies use methods that can accommodate conceptually and practically diverse data and divergent epistemologies. Other tools promoted in this context are for example agent-based and participatory modelling (Pahl-Wostl, 2002). In the past fifteen years, a variety of innovative learning tools emerged that employ models in social settings, both in an educational and a professional context. There is not always a clear distinction between tools for the one or the other context. We observe an overlap between tools applied in universities for teaching and in practice for collaborative planning processes (Ubbels and Verhallen, 2000, 2001) or social learning (Pahl-Wostl, 2002).

The progress of computer technology, the way young people interact with interactive digital media and positive experiences with "activated learning" offer new possibilities for integration and interdisciplinary teaching (Kirriemuir and McFarlane, 2004; Pivec, 2007; Prensky, 2001). It is impossible to provide here a review of simulation games and role plays employed in water management courses at universities worldwide, because inventories of such tools are not available and are difficult to make, since educational materials are not monitored like scientific publications and often not (yet) made available online. Table 1 shows a number of simulation games and role plays in the field of water management.

In this paper, I will discuss my experience with one game and one role play that I developed a number of years ago and that I have played many times in different educational settings in the past few years: the River Basin Game and the
Globalization of Water Role Play. After presenting the setup for each play, I will reflect on the instructional value, particularly considering the effectiveness of the play in providing for interdisciplinary training. The paper will close with a general discussion of the potential of computer-supported games and role plays in teaching interdisciplinary water management.

\section{The River Basin Game}

\subsection{Set-up of the game}

The River Basin Game was developed as a tool to illustrate the "common-pool resource" character of water within a river basin (Hoekstra, 2007). The learning objective is to understand the risk of over-abstraction of water within a river basin as a result of its common-pool resource character and the downstream effects of upstream water consumption. The primary target group of the game is formed by university students, but it can also be played with academic colleagues or water professionals and even in secondary school. The game can actually be played at different levels; one will have to adjust the explanations and feedback according to the level of the participants.

Participants play farmers who try to optimise their benefits in farming. Each farmer has enough fertile land; water is the limiting factor. Farmers can irrigate their crops and optimise their water use such that they achieve the highest benefit from the water. The aim for each individual farmer is to achieve the highest personal net benefit possible.

The farmers living in one river basin compete for the water in that river basin. The river basin is schematised into three compartments: upstream, midstream and downstream. In each compartment there are three to five farmers. The total number of farmers in a river basin is thus nine to fifteen. If there are many more participants, one can play a number 
of parallel games, representing independent river basins. At the start of the game, the participants negotiate who is going to play an upstream, midstream or downstream farmer. The clear advantage of upstream is that the farmer is "first in use". However, the downstream advantage is that there is naturally more water.

The game consists of eight rounds, each one corresponding to one meteorological year. Playing one round will ideally take about fifteen minutes: ten minutes for deciding on the size of water abstraction and five minutes for feedback from the facilitator.

What an individual farmer will earn depends upon his decision on how much water he abstracts for irrigating his fields, and upon the decisions that others in the basin make. In particular, farmers need to be concerned about the total water footprint of crop production in the basin, because it may affect the hydrology of the basin and thus the availability of water and the costs of water abstraction. The water footprint of farming is defined as the volume of irrigation water that evaporates during crop production or is incorporated into the crop. In the game it is assumed that all water abstracted is evaporated or incorporated into the crop and thus lost for the basin. The total water footprint in each compartment depends on how much the farmers in that compartment abstract. If the water footprint in a compartment increases, water will become scarcer and the costs of abstraction will increase. In addition, the water footprint in the upper compartments will reduce the water availability downstream and thus increase downstream costs of abstraction.

In each round, each farmer makes a decision on how many water units he abstracts for irrigating his fields. Water abstraction by individual farmers will be strictly anonymous, known only to farmers themselves and the facilitator. In each round, the gross benefit of a farmer will depend on the number of water units abstracted $(A)$ by that farmer and the benefit per unit $\left(B_{\text {unit }}\right)$. The benefit per unit of water is equal throughout the game: 50 Euro per unit of water. The total cost of water abstraction for a farmer will be equal to the number of water units abstracted $(A)$ times the average cost of each unit $\left(C_{\text {unit }}\right)$. In each round $n$, the net benefit $\left(B_{\text {net }}\right)$ that a farmer obtains from the number of water units abstracted will be equal to the difference between the gross benefit and the cost in that round:

$$
B_{\text {net }}[n]=A[n] \times\left(B_{\text {unit }}-C_{\text {unit }}[n]\right) .
$$

The average unit cost will increase when the farmers in a compartment abstract more units. The first unit abstracted within a compartment in the first round will cost 1 Euro. The second unit abstracted in the same compartment will cost 2 Euro. The third unit will cost 3 Euro, and so on. Each additional water unit will thus cost 1 Euro more than the previous water unit abstracted. For example, suppose that in round 1 the farmers in one compartment together abstract 100 units. The total cost of all the units abstracted will equal: $1+2+3+\ldots+100=5050$ Euro. The average unit cost will be $5050 / 100=50.5$ Euro. It can easily be seen that the average unit cost will always be half way between the cost of the first unit abstracted and the cost of the last unit abstracted. The average unit cost does not only depend on how much water one particular farmer uses, but also on how much the other farmers within the same compartment use. The facilitator will provide the farmers with the actual average unit cost at the end of each round. Only in round 1 does the first water unit cost 1 Euro. In round 2, the cost of the first unit can be higher if in the round before depletion has taken place. The rule is: if the water storage in a compartment has been depleted by $x$ water units (compared to the initial water storage in the first year), the cost of the first water unit in a next round is $1+x$ Euro. For each compartment, the cost of the first water unit in round $n\left(C_{\text {unit,i[ }}[n]\right)$ is thus 1 Euro plus the difference between the initial water storage in year $n\left(S_{i}[n]\right)$ and the initial water storage in year $1\left(S_{i}[1]\right)$.

$C_{\text {unit, } \mathrm{i}}[n]=1+S_{i}[n]-S_{i}[1]$.

Since individuals cannot know the depletion rate, the facilitator will provide the farmers with information about the cost of the first water unit at the start of each new round. Each farmer has an individual record sheet. During the game, each farmer will have to fill in one row for each round. Per row, the farmer fills in the number of units abstracted in that round, the gross benefit in that round, the total cost and net benefit. The latter three can be calculated by the farmer based on the number of water units abstracted, gross benefit per unit abstracted and average unit cost. Per round, each farmer writes the number of water units abstracted on another small decision card for that round and hands that in to the game facilitator. At the end of each round, the facilitator gives feedback on the total net benefit in a basin in the past round, the average cost of one unit of water in the past round (per compartment) and the cost of the first unit of water for the next round (again per compartment).

Figure 1 shows how the river basin is schematised into three spatial compartments. Incoming and outgoing water flows are represented by arrows. The water balance of a compartment over one year (one round $n$ ) looks as follows:

$$
\Delta S[n]=P_{\text {net }}[n]+Q_{\text {in }}[n]-Q_{\text {out }}[n]-\Sigma A[n],
$$

in which $\Delta S$ is the change of water storage in the compartment, $P_{\text {net }}$ is net precipitation, $Q_{\text {in }}$ the inflow from upstream, $Q_{\text {out }}$ the outflow and $\Sigma A$ the total of water abstractions from the different farmers within the compartment. The outflow from a compartment in year $n$ depends on the initial water storage in that year $\left(S_{i}\right.$, that is, the water storage at the start of the year) and the so-called "lag time" $k$ of the compartment:

$Q_{\text {out }}[n]=S_{i}[n] / k$.

The value of $k$ is $1.25 \mathrm{yr}$ for all three compartments. If, for example, the water storage in a compartment is 50 units 
Table 2. Variables in the River Basin Game with their values for year 1.

\begin{tabular}{lllccc}
\hline Variable & Symbol & Unit & Upstream & Midstream & Downstream \\
\hline Initial water storage & $S_{\mathrm{i}}$ & water units & 50 & 75 & 100 \\
Outflow & $Q_{\text {out }}$ & water units/year & 40 & 60 & 80 \\
Net precipitation & $P_{\text {net }}$ & water units/year & 40 & 20 & 20 \\
Inflow from upstream & $Q_{\text {in }}$ & water units/year & - & 40 & 60 \\
Water abstraction & $A$ & water units/year & $?$ & $?$ & $?$ \\
\hline
\end{tabular}

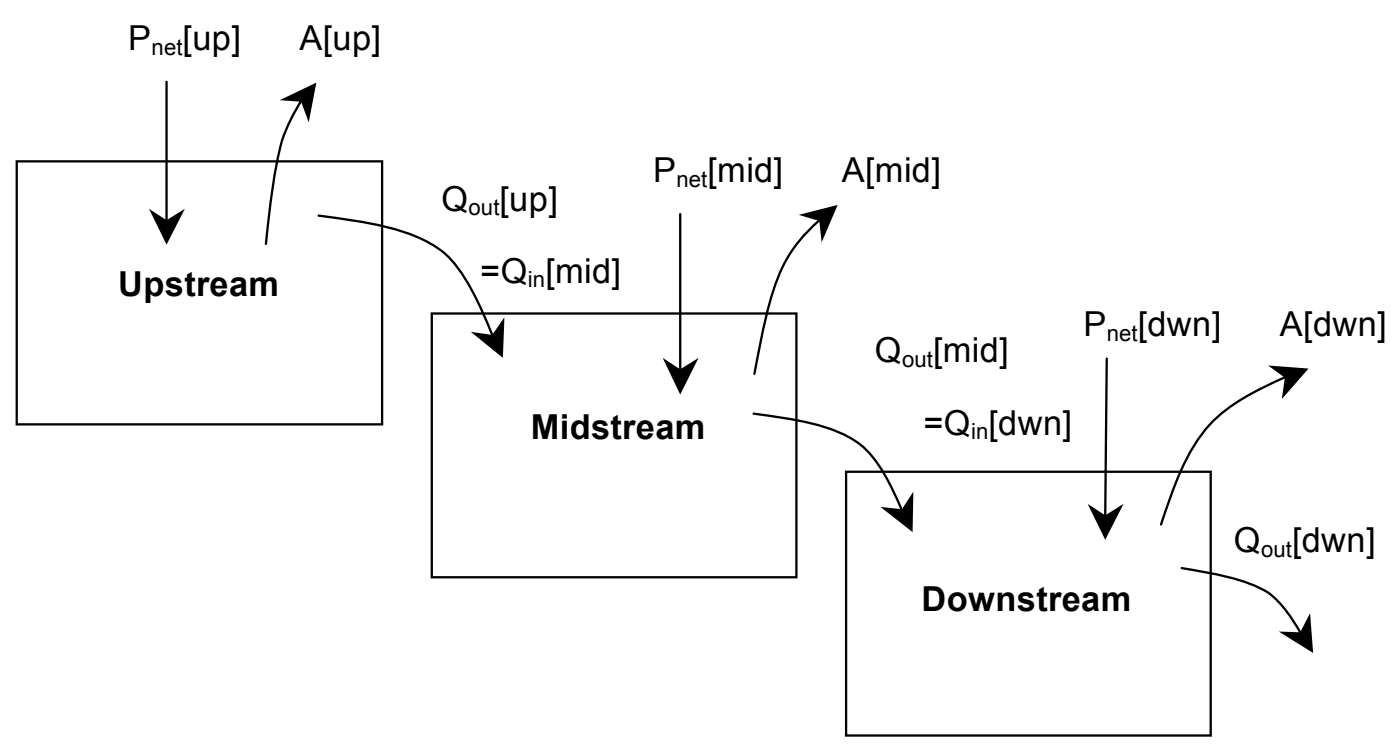

Fig. 1. The river basin schematisation in the River Basin Game.

at the start of a year, the outflow in that year will be $50 / 1.25=40$ units. Table 2 shows all relevant data for round 1 . In the past, water abstractions in the basin were zero, so that in the initial situation the outflow of each compartment is equal to the net precipitation plus inflow from upstream. The net precipitation will remain constant in each round, but the other variables will change if farmers start abstracting water for irrigation.

\subsection{Experiences with the game}

In the period 2007-2011, I played the River Basin Game about fifteen times, mostly in classroom settings with MSc students. The game is also freely available online (at www. waterfootprint.org), so the game is possibly also used by others, but I have not monitored that. The game is generally rated as the best component in my courses. Many of my former students remember me most in particular because of the games we played in classes. It seems to be the intense experience that makes students remember the game. During the game, students generally get quite animated, because some try to convince others about certain "best" abstraction volumes, others try to cheat despite certain agreements about abstraction limits, and yet others focus on setting up a reasonable negotiation process. Sometimes creative solutions are found, like farmers quitting altogether (to seek their fortunes in the big city). A more regular solution arrived at by students is to agree on a maximum abstraction volume per farmer (generally agreed per compartment, not over the river basin as a whole), but coming to agreements about enforcement of the agreement appears to be always hard and generally does not happen. As an alternative to regulation through setting a maximum abstraction level, students sometimes create economic incentives like an abstraction tax. Incidentally, it happens that a student computes the "best" solution per compartment and tries to put that finding into negotiations, but most common is that students find a reasonable abstraction rate after a few rounds by bitter experience.

After finalizing the last round, time is generally taken to reflect on the game and make an inventory among participants of lessons learned. Even though participants are often already aware of the risks of overexploitation of a commonpool resource and about the problem of downstream effects of upstream abstractions, it never happens that participants manage to exploit the water for optimal benefit during the first few rounds. They will always overexploit first. It often happens that even in the last round no sustainable equilibrium is found, due to misunderstanding with some and intentional 
free-rider behaviour by others. The most essential lesson learned from this game is that the risk of over-abstractions in a river basin can be rationally understood given the complexity of the system, the conflict between individual and group optimums and the difficulty in achieving good cooperation.

In the introduction, the participants receive sufficient information to compute the optimal group benefit. If participants would (a) carefully study the case, (b) understand the basic hydrology and economics that underlies the game, (c) have some basic mathematical skills and (d) be able to come to an agreement amongst each other about fair and efficient water sharing, they could perform well from the first round on. However, it always appears that at least one of the conditions is not met, mostly none of them. Even though both the hydrology and economics applied in the game are very simple - students have generally learned this in earlier courses - it appears difficult to comprehend lessons from different disciplines in a "real-world" setting. The basic hydrologic knowledge required in this game is understanding how one can compute water storage change in a number of time steps based on a water balance. It would further be useful that one understands the principle of a "linear reservoir" (a reservoir whereby outflow linearly depends on storage, see Eq. 4). The basic economic knowledge required is understanding marginal cost and benefit curves. Some mathematical skills would be required if somebody would really like to compute what is "best". However, for actually playing the game it is not necessary to compute at all, so mathematical knowledge is hardly required.

What is interesting in this game is that learning will always happen. Even if participants consistently fail to understand the underlying hydrology and economics, have no clue at all how one could ever make useful computations and if they would not succeed in making cooperative agreements, they will still learn by trial and error. The basic lesson - the risk of over-abstraction - will always come through. The ambition, however, is of course that students deepen their understanding beyond that. The game appears to invite students to try to better understand what really happens in the system they are dealing with and to be creative in finding cooperative solutions. By providing feedback after each round and more extensive discussion after the last round, a number of learning points generally evolve. The basic lesson is the risk of "the tragedy of the commons":

- Within one river basin compartment, water can be regarded as a "common-pool resource", which means that the farmers in that compartment have equal access to the water in that compartment and that additional water use by one is at the cost of the group as a whole.

- Within one river basin compartment: $\Sigma$ (individual optima) $\neq$ group optimum.

- At all times there is the risk of one or more free riders.
- Cooperation does not easily establish itself, although this is - in the end - in the interest of all.

More specifically, participants learn about the tragedy of the commons in a dynamic system:

- There is a tendency to go for short-term benefits, at the cost of long-term benefits.

- Due to the dependency of one year on the previous year: $\Sigma($ year optima $) \neq$ optimum over period of years.

- It is difficult to recover from poverty and environmental degradation, because environmental restoration (e.g. recovering of the groundwater table) requires temporarily strongly reduced use while the poverty conditions do not allow for that.

- Assessing what is the optimum becomes more difficult if not only dependency between years does exist but also differences between years (e.g. variability in annual rainfall).

In addition, lessons emerge from the upstream-downstream setting:

- The upstream users have the advantage of having the first opportunity to use the water.

- The upstream water footprint subtracts from downstream water availability, but upstream users do not account for that in their decisions about water use.

- $\Sigma$ (compartment optima $) \neq$ river basin optimum.

General lessons from the game are further:

- Full knowledge of the natural system is insufficient to solve the problem. The problem is not only about resource scarcity, but also about how to come to forms of cooperation (institutional arrangements) that improve group performance.

- Full knowledge is unachievable, making decisions and cooperation even more difficult.

- Creative solutions are possible, but farmers must (1) find them, (2) get everybody committed, and (3) agree on enforcement mechanisms.

Among the many alternative possible cooperative arrangements, students often arrive at the following sorts of solutions:

- Create a forum for sharing information. Agree on making abstractions publicly known.

- Agree on a maximum abstraction per compartment and share the total volume among the farmers within the compartment. Agree on an enforcement mechanism. 
Table 3. The four countries in the Globalization of Water Role Play.

\begin{tabular}{lllll}
\hline & Country A & Country B & Country C & Country D \\
\hline Climate & Temperate & Mediterranean & (Sub)tropical wet & (Sub)tropical dry \\
Development status & Developed & Developed & Developing & Developing \\
Water endowment & Humid & Semi-arid & Humid & Semi-arid \\
Water productivity & High & Very high & Very low & Low \\
\hline
\end{tabular}

- Internalise externalities: let the upstream farmers cover the additional costs incurred by the downstream farmers as a result of upstream water abstractions.

- Agree on the leave of some of the farmers (there seems to be little place for all of them) and pay them a few years so they can develop other work ...

The interesting thing of the game is that participants learn about the importance of combining knowledge of the physical and economic system with understanding social interactions. On the one hand, they discover the natural dynamics of water flow in a river basin (water balance, runoff and delay) and get to understand how a growing water footprint contributes to water scarcity and rising costs. On the other hand, they get acquainted with free-rider behaviour when depending on a common-pool resource; experience social dynamics around common-pool resource use; and learn about incentives and barriers to cooperation.

\section{The Globalization of Water Role Play}

\subsection{Set-up of the role play}

The Globalization of Water Role Play has been developed by a team of the University of Twente, the Netherlands, in a project commissioned by the World Bank Institute (Hoekstra et al., 2009). The game can be obtained for free through the Water Footprint Network (www.waterfootprint.org). The theoretical basis for the role play was formed by the book Globalization of Water (Hoekstra and Chapagain, 2008). The role play can be used as an introduction to or illustration of the theory treated in that book, but can be played as a standalone learning tool as well.

The aim of the role play is to convey the message that wise water resources management is not simply a national matter, but to be understood in a global context. Global water use efficiency can be increased through wise trade in water-intensive commodities. The result of trade, however, is that national water footprints are externalized (contributing to increased water scarcity elsewhere) and that water becomes a geopolitical factor (through international resource dependencies).

The setting is a world with four countries. The countries fundamentally differ in terms of climate, development, water availability and water productivity (Table 3 ). The ideal number of participants is twelve persons - three persons per country. When there are more than twelve people, one can run multiple versions of the role play at different tables. There are three roles per country: a Head of State, who coordinates decisions and focusses on the national economy; a Minister of Environment and Agriculture, responsible for allocating water in a sustainable manner; and a Minister of Trade and Foreign Affairs, responsible for negotiating trade with other countries and keeping relations with other countries. The economy consists of five sectors: food grains; vegetables and fruits; meat and dairy; cotton; and bio-energy.

The role play is played in up to six rounds. Each round corresponds to one year. Playing one round will take about $30 \mathrm{~min}$ : $20 \mathrm{~min}$ for making decisions on water allocation, production, trade and consumption in that round and $10 \mathrm{~min}$ for feedback from the facilitator.

In each country, the government tries to increase the national development level, which is reflected by six development indicators: food supply (supply of grains, vegetables and fruits, meat and dairy); welfare (weighted supply of food, cotton and bio-energy); extent of meeting environmental water needs; size of national water footprint; amount of national water saving through international trade; and dependency on foreign water resources. All indicators are clearly defined (Table 4), such that participants can monitor the status of the indicators based on the available information and their own decisions.

In each round, each national government needs to make the following decisions: (1) allocate the available green water resources (rainwater) and blue water resources (ground/surface water flows) over the five sectors of economy and the environment; (2) decide, per sector, how the produced commodities are distributed over consumption and export; and (3) exchange the exports for other commodities from other countries. Imported commodities are used for consumption. Commodities can be internationally traded through barter. The price of commodities in terms of another commodity is to be negotiated between the trading countries.

At the start of the role play, each participant receives a handout with a short background and an explanation of the role play. The participants also receive, per country, details on available green and blue water resources (in $\mathrm{m}^{3} \mathrm{yr}^{-1}$ ), environmental water needs (which fractions of the green and blue water resources are ideally be reserved for nature), and 
Table 4. Development indicators in the Globalization of Water Role Play.

\begin{tabular}{|c|c|c|c|}
\hline Category & Indicator & Unit & Calculation \\
\hline Food supply & $\begin{array}{l}\text { Grain supply } \\
\text { Vegetable and fruit supply } \\
\text { Meat and dairy supply }\end{array}$ & $\begin{array}{l}\mathrm{kg} \mathrm{yr}^{-1} \mathrm{cap}^{-1} \\
\mathrm{~kg} \mathrm{yr}^{-1} \mathrm{cap}^{-1} \\
\mathrm{~kg} \mathrm{yr}^{-1} \mathrm{cap}^{-1}\end{array}$ & $\begin{array}{l}C_{1}=\text { Production }+ \text { Import }- \text { Export } \\
C_{2}=\text { Production }+ \text { Import }- \text { Export } \\
C_{3}=\text { Production }+ \text { Import }- \text { Export }\end{array}$ \\
\hline $\begin{array}{l}\text { Economic } \\
\text { development }\end{array}$ & $\begin{array}{l}\text { Welfare } \\
\text { - Food supply indicator } \\
\text { - Cotton supply indicator } \\
\text { - Bio-energy supply indicator }\end{array}$ & $\begin{array}{l}- \\
- \\
- \\
-\end{array}$ & $\begin{array}{l}W=1 / 3 \times[F+C+B] \\
F=1 / 3 \times\left[\operatorname{MIN}\left(1, C_{1} / C_{1, \text { ref }}\right)+\operatorname{MIN}\left(1, C_{2} / C_{2, \text { ref }}\right)\right. \\
\left.\quad+\operatorname{MIN}\left(1, C_{3} / C_{3, \text { ref }}\right)\right] \\
C=C_{4} / C_{4, \text { ref }} \\
B=C_{5} / C_{5, \text { ref }}\end{array}$ \\
\hline Environment & $\begin{array}{l}\text { Meeting environmental flow } \\
\text { requirements }\end{array}$ & $\%$ & $\begin{array}{l}\mathrm{EF}=100 \times(\text { Water endowment }- \text { Water } \\
\text { footprint of production }) / \text { Environmental flow requirement }\end{array}$ \\
\hline \multirow[t]{3}{*}{$\begin{array}{l}\text { Water } \\
\text { footprint }\end{array}$} & Green water footprint & $\mathrm{m}^{3} \mathrm{yr}^{-1} \mathrm{cap}^{-1}$ & $\begin{array}{l}\mathrm{WF}_{\mathrm{g}}=\text { Water use behind consumed commodities that were } \\
\text { made with green water }\end{array}$ \\
\hline & Blue water footprint & $\mathrm{m}^{3} \mathrm{yr}^{-1} \mathrm{cap}^{-1}$ & $\begin{array}{l}\mathrm{WF}_{\mathrm{b}}=\text { Water use behind consumed commodities that were } \\
\text { made with blue water }\end{array}$ \\
\hline & $\begin{array}{l}\text { Water footprint as } \% \text { of average } \\
\text { global water availability }\end{array}$ & $\%$ & $\begin{array}{l}\text { Share }=100 \times \text { Total water footprint per capita/Global water } \\
\text { availability per capita }\end{array}$ \\
\hline \multirow[t]{2}{*}{ Water saving } & National green water saving & $\mathrm{m}^{3} \mathrm{yr}^{-1} \mathrm{cap}^{-1}$ & $\begin{array}{l}S_{\mathrm{g}}=\text { Net import of commodities produced with green water/ } \\
\text { green water productivities }\end{array}$ \\
\hline & National blue water saving & $\mathrm{m}^{3} \mathrm{yr}^{-1} \mathrm{cap}^{-1}$ & $\begin{array}{l}S_{\mathrm{b}}=\text { Net import of commodities produced with blue water/ } \\
\text { blue water productivities }\end{array}$ \\
\hline Dependency & Dependency on foreign resources & $\%$ & $D=100 \times$ External water footprint/Total water footprint \\
\hline
\end{tabular}

green and blue water productivities $\left(\mathrm{kg} \mathrm{m}^{-3}\right)$ for the five sectors of economy: food grains, vegetables and fruits, meat and dairy, cotton, and energy crops.

Each country has its own game board (Fig. 2). Each round, the participants start with putting the amount of available green and blue water resources on the proper fields in the upper part of the board. Hereto they use small cards representing certain amounts of "water units". Next, they allocate the available green and blue water by moving the water units down to the various sectors of economy and the environment. Per economic sector, the green and blue water resources allocated will produce a certain amount of commodity, depending on the water productivities. The participants exchange the "water units" for "commodity units". Per economic sector, the commodity units obtained can be used for consumption or export to other countries. The Minister of Trade and Foreign Affairs can exchange the commodities for export for other commodities from another country. Final consumption depends on the commodities produced domestically plus the imported commodities obtained through barter trade. At the end of a round, participants remove all commodities from the consumption field and start all over again.

Per country, one of the participants is asigned to record, for each round, the water allocation decisions, the amounts of commodities produced, the amounts traded and the final amounts consumed. At the end of each round, this person hands over the filled record sheet to the facilitator, who will feed the record into a computer model in Excel that calculates the status of the six development indicators. At the end of each round, the facilitator gives feedback to all countries - in the form of a World Development Report and a brief presentation - on the development status in each country.

\subsection{Experiences with the role play}

In the period 2009-2011, the role play was played, facilitated by me or one of my team, fifteen times, in both professional and academic settings, in different countries (Netherlands, US, China, Brazil, the United Arab Emirates). In most of the cases, the group of participants was highly diverse, originating from various continents. In addition, fifteen (free) user licenses were provided to other organisations (mostly universities) around the world; whether they actually played the role play and how often, has not been monitored.

Most of the time, the role play has been played as part of a larger course. Invariably, the role play is rated by participants among the best parts of the course. Typical feedback is "I liked the role play most", "that was really fun", and "very instructive". Playing the role play takes four hours, so one 

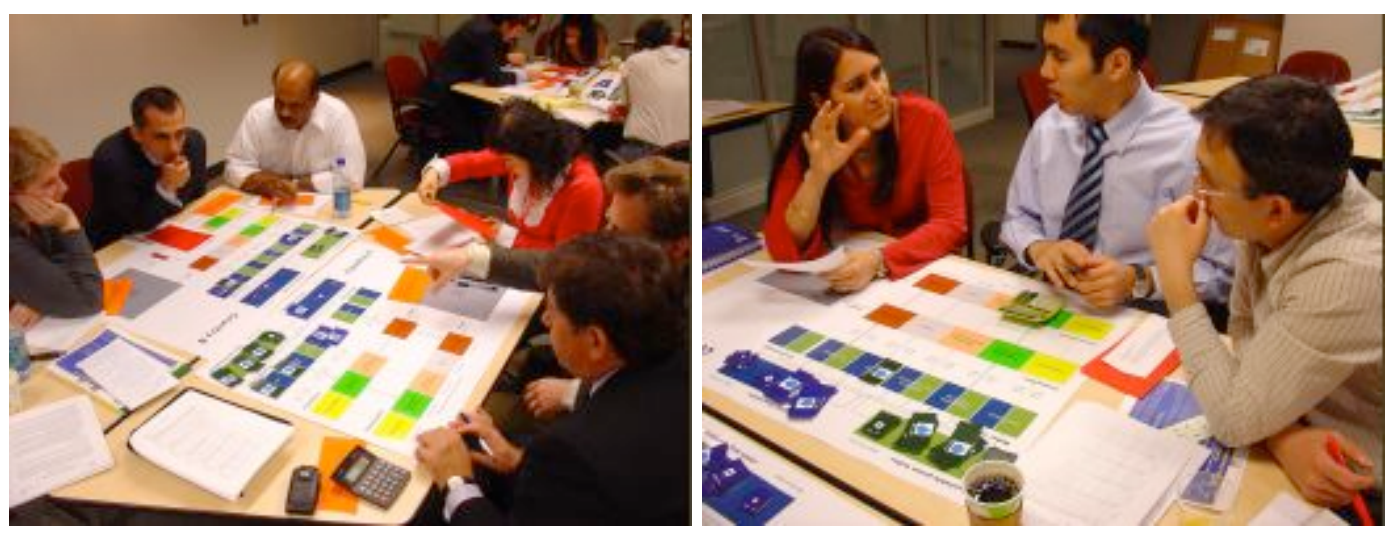

Fig. 2. Playing the Globalization of Water Role Play.

may wonder whether not the same or more learning effect can be achieved through four hours lecturing. In my experience, in four hours lecturing, more topics can be presented than what is covered by the scope of the role play. However, the question is, of course, what people will remember better. Without question, the role play stays in the memories of participants more than a series of lectures. Besides, and this is probably most important, the role play inevitably offers the material in an integrated setting, in which cognitive understanding, social interaction, uncertainties and different worldviews all come together. Participants experience that "doing well" in the play depends more on understanding the complexity and coherence of the whole than on understanding single elements in the play, and that good cooperation and acting strategically is more important than being able to compute the "best solution".

Once we played the role play in China, with most participants coming from China itself. More than other times, the participants focused on trying to compute what would be the best water resources allocation. At the end of the play, one participant said that he had highly appreciated the play, but that it would have been better if they had had more prior knowledge (we played the role play at the very start of a course), because it would have enabled him to play "better". The experience in China shows the relative emphasis in Chinese education on cognition and analytics. Of course, the success of the role play in terms of learning does not depend on how "well" the role play is being played. Learning goes through making errors. Indeed, in the Chinese case, but also in the other cases in which we played the role play, the importance of strategy and communication is increasingly recognised in the course of the play. A best solution does not exist in the role play because different development indicators will always be weighed differently by the various players. Playing is thus not a matter of optimisation, as some players often initially see the challenge.

In the reflection session after the last round, we always reflect on the lessons learned. These generally classify into two categories: lessons about how the "system" works (the play characteristics) and lessons about social interaction and strategy. I usually ask also how realistic participants find the play and what elements are unrealistic. In my experience, a game or role play is most successful if it incorporates a selected number of parameters and mechanisms, namely those parameters and mechanisms that you want the participants to get experience with. As a result, any game or role play excludes a lot of factors that are relevant in reality as well. In the Globalization of Water Role Play, water is the only production factor, which is not realistic. However, it makes participants focus on the relevance of this production factor and observe its significance in enlarged form. Further, the role play has fixed productivities in time, while they can improve over time in reality. In addition, every round (each year), countries will have the same water endowment as the other years, while in reality there is climate variability. All such parameters can easily be brought into the game, but that would make it more complex and deviate the attention of the participants from the main intended learning points of this role play, and possibly even obscure them.

In the reflection session, participants will generally list most of the lessons that through its setup are built into the play: international trade in water-intensive products gives a global dimension to water as a resource; countries can profit from trade if they use their comparative advantage in producing specific commodities; smart trade will result in national water savings and reduce the total water footprint of a country; through trade, countries will have an external water footprint and become dependent on other countries; there is a tension between self-sufficiency and efficiency; there is a conflict between the different water-demanding sectors and between water for production versus water for nature; water productivities vary across sectors; blue water productivities are generally higher than green water productivities; and international cooperation can be to the benefit of all. 


\section{Discussion and conclusion}

In both examples given in the previous two sections, the plays offer "a system" to be dealt with. The challenge lies both in understanding the system and in the formulation of good strategies of action. In both cases, the system is a simplified representation of reality, whereby the system variables and mechanisms have been selected according to the learning goals of the play. The two plays show that participants learn through experience. Usually, participants initially focus on trying to understand the system; only in later stages of the play they recognise that social interaction and cooperation are as important to arrive at desired outcomes. An important lesson, particularly for engineers and economists playing the games, is that thinking in terms of the "best" solution is not very helpful, partly because of the uncertainties among participants about the working of the system, but more importantly because of the different values and perspectives of the participants.

Good experience with two plays in teaching students and professionals in the field of water management is not a proof of the effectiveness of plays in general. Measuring the effectiveness of different didactic methods is not an easy task. Research on this topic suggests that the effectiveness of active learning methods compared to traditional lectures depends on a range of factors, including contextual factors and student characteristics (Struyven et al., 2011). In other words, the effectiveness of active learning tools like games and role plays cannot be measured as a function of the properties of the tools alone. In my experience with the River Basin Game and the Globalization of Water Role Play, the way the facilitator employs the tools and the way in which play sessions are embedded in a broader course, critically matter. However, I have not undertaken research into this specific question. In my personal experience, and based on the evaluations of students, I maintain that games and role plays are promising didactic tools offering interdisciplinary teaching in the field of water management. In my experience, these tools are not to be seen as replacements for lectures, but rather as enrichment to lectures.

Acknowledgements. I thank Mesfin Mekonnen and Winnie Gerbens-Leenes, both at the University of Twente, Enschede, the Netherlands, for their contribution in developing the Globalization of Water Role Play. I thank the World Bank Institute, Washington DC, USA, for funding the development of the role play and Mei Xie for her valuable suggestions in the development process.

Edited by: J. Seibert

\section{References}

Blöschl, G., Carr, G., Bucher, C., Farnleitner, A. H., Rechberger, H., Wagner, W., and Zessner, M.: Promoting interdisciplinary education - the Vienna Doctoral Programme on Water Resource Systems, Hydrol. Earth Syst. Sci., 16, 457-472, doi:10.5194/hess16-457-2012, 2012.

Farczadi, L., De Groen, M. M., and Heun, J. C.: Ravilla-2: Water resources management roleplay, IHE Delft, Delft, The Netherlands, 1999.

Farczadi, L., De Groen, M. M., and Heun, J. C.: Ravilla: Simulation of water resources management under alternative institutional settings, UNESCO-IHE, Delft, The Netherlands, 2008.

Haasnoot, M. and Van Beek, E.: Sustainable Delta: a serious game for exploring pathways, R \& D Highlights 2010, Deltares, Delft, The Netherlands, 24-25, 2010.

Heun, J. C.: LIBRA simulation of integrated river basin planning, UNESCO-IHE, Delft, The Netherlands, 2011.

Hoekstra, A. Y.: River basin game, available at: www. waterfootprint.org/?page=files/Riverbasingame, last access: 11 July 2012, University of Twente, Enschede, The Netherlands, 2007.

Hoekstra, A. Y. and Chapagain, A. K. : Globalization of water: Sharing the planet's freshwater resources, Blackwell Publishing, Oxford, UK, 2008.

Hoekstra, A. Y., Mekonnen, M. M., and Gerbens-Leenes, P. W.: Role play on globalization of water management: Interactive learning about water footprint and virtual water trade, available at: www.waterfootprint.org/?page=files/RolePlay, last access: 11 July 2012, University of Twente, Enschede, The Netherlands/World Bank Institute, Washington, DC, USA, 2009.

Hufschmidt, M. M.: The role of universities in water resources education: The social sciences, Water Resour. Res., 3, 3-9, 1967.

Jaspers, F.: Roleplay international rivers: Shared vision and strategy development, IHE Delft, Delft, The Netherlands, 2000.

Kirriemuir, J. and McFarlane, A.: Literature review in games and learning, Report 8, Futurelab Series, Bristol, UK, 2004.

Lankford, B., Sokile, C. S., Yawson, D., and Lévite, H.: The river basin game: A water dialogue tool, Working Paper 75, International Water Management Institute, Colombo, Sri Lanka, 2004.

Magombeyi, M. S., Rollin, D., and Lankford, B.: The river basin game as a tool for collective water management at community level in South Africa, Phys. Chem. Earth, 33, 873-880, 2008.

Maier, H. R., Baron, J., and McLaughlan, R. G.: Using online roleplay simulations for teaching sustainability principles to engineering students, Int. J. Eng. Educ., 23, 1162-1171, 2007.

McLaughlan, R. G.: Instructional strategies to educate for sustainability in technology assessment, Int. J. Eng. Educ., 23, 201-208, 2007.

Pahl-Wostl, C.: Towards sustainability in the water sector - The importance of human actors and processes of social learning, Aquat. Sci., 64, 394-411, 2002.

Pivec, M.: Play and learn: Potentials of game-based learning, British J. Educ. Technol., 38, 387-393, 2007.

Porte Agel, F. F., Heun, J. C., and Savenije, H. H. G.: Water demand management - Roleplay: trainers' manual, IHE Delft, Delft, The Netherlands, 1996. 
Prat, P., Aulinas, M., Turon, C., Comas, J., and Poch, M.: Role playing games: a methodology to acquire knowledge for integrated wastewater infrastructures management in a river basin scale, Water Sci. Technol., 59, 1809-1816, 2009.

Prensky, M.: Digital game-based learning, McGraw-Hill, New York, USA, 2001.

Schmidt, A. L.: Role play on river and floodplain management: Player manual STORM-RR, IHE Delft, The Netherlands, 1998.

Seibert, J. and Vis, M. J. P.: Irrigania - a web-based game about sharing water resources, Hydrol. Earth Syst. Sci., 16, 2523-2530, doi:10.5194/hess-16-2523-2012, 2012.

Struyven, K., Dochy, F., and Janssens, S.: Explaining students' appraisal of lectures and student-activating teaching: perceived context and student characteristics, Interact. Learn. Environ., doi:10.1080/10494820.2010.500084, in press, 2011.

Ubbels, A. and Verhallen, A. J. M.: Suitability of decision support tools for collaborative planning processes in water resources management, Report RIZA 99.067, Institute for Inland Water Management and Wastewater Treatment, Lelystad, The Netherlands, 2000.

Ubbels, A. and Verhallen, A. J. M.: The use of role-playing in integrated water management, Regional Management of Water Resources, Proceedings of a symposium held during die Sixth IAHS Scientific Assembly at Maastricht, The Netherlands, July 2001, IAHS Publ. No. 268, 191-197, 2001.
Uhlenbrook, S. and de Jong, E.: T-shaped competency profile for water professionals of the future, Hydrol. Earth Syst. Sci. Discuss., 9, 2935-2957, doi:10.5194/hessd-9-2935-2012, 2012.

Valkering, P., Tàbara, J. D., Wallman, P., and Offermans, A.: Modelling cultural and behavioural change in water management: An integrated, agent based, gaming approach, Integr. Assess. J., 9, 19-46, 2009.

Valkering, P., Van der Brugge, R., Offermans, A., Haasnoot, M., and Vreugdenhil, H.: A perspective-based simulation game to explore future pathways of an interacting water-society system, Simul. Gaming, doi:10.1177/1046878112441693, in press, 2012.

Van Deursen, W., Haasnoot, M., Offermans, A., and Van Lieshout, M.: Duurzame Delta: een serieus spel over de toekomst van het waterbeheer, $\mathrm{H}_{2} \mathrm{O}$, Nijgh Periodieken, Schiedam, The Netherlands, 25/26, 28-29, 2010.

Wittfogel, K. A.: Oriental despotism: A comparative study of total power, Yale University Press, New Haven, USA, 1957. 